\title{
APLIKASI PUPUK ORGANIK HAYATI, KIMIA DAN METODE KONSERVASI TANAH UNTUK MENINGKATKAN HASIL KENTANG (Solanum tuberosum L.) PADA ANDISOL DI BREBES
}

\author{
Application of Biofertilizer, Chemical Fertilizers and Soil Conservation Methode for \\ Increasing Potato Yield (Solanum tuberosum L.) on Andisol Brebes
}

\author{
Naimatul Khoiriyah, Tamad dan Joko Maryanto* \\ Program Studi Agroteknologi, Fakultas Pertanian Universitas Jenderal Soedirman \\ J1. dr. Soeparno Purwokerto
}

*Alamat Korenspondensi: jmaryanto@yahoo.com

\begin{abstract}
ABSTRAK
Penelitian ini bertujuan untuk mengetahui pengaruh pupuk organik hayati, kimia dan metode konservasi tanah terhadap hasil kentang di andisol, serta hubungan hasil kentang dan serapan P dengan perlakuan pupuk organik hayati, kimia dan metode konservasi di andisol. Penelitian dilakukan bulan Maret-Desember 2017 di Desa Pandansari, Paguyangan, Brebes dan Laboratorium Ilmu Tanah, Fakultas Pertanian, Universitas Jenderal Soedirman, Purwokerto. Rancangan percobaan yang digunakan adalah RAK faktorial dengan tiga faktor. Faktor pertama yaitu pupuk organik (P) dengan 6 taraf terdiri dari P1 (kontrol), P2 (POH 20 ton/ha), P3 (POH 15 ton/ha), P4 (POH 10 ton/ha), P5 (POH 5 ton/ha) dan P6 (POH 2,5 ton/ha). Faktor kedua adalah pupuk kimia (K) dengan 4 taraf yaitu K1 (kontrol), K2 (dosis anjuran dan $200 \mathrm{~kg}$ kapur), K3 (1/2 dosis anjuran dan $200 \mathrm{~kg}$ kapur) dan K4 (1/4 dosis anjuran dan $200 \mathrm{~kg}$ kapur). Faktor ketiga yaitu lereng dengan 3 taraf, yang terdiri dari L1 (kontrol), L2 (bedengan sejajar kontur miring 10\%) dan L3 (bedengan sejajar kontur). Variabel yang diamati yaitu tinggi tanaman, jumlah daun, hasil kentang, $\mathrm{pH} \mathrm{H}_{2} \mathrm{O}$, dan serapan $\mathrm{P}$. Hasil penelitian menunjukkan bahwa pupuk organik hayati dan kimia dengan metode konservasi tanah berpengaruh terhadap hasil kentang di andisol dan terdapat hubungan korelasi antara hasil kentang dan serapan P.
\end{abstract}

Kata kunci: serapan P, hasil kentang dan andisol

\begin{abstract}
This study aims to determine the effect of biological organic fertilizer, chemistry and soil conservation methods on the results of potatoes at andisol, as well as the relationship between potato yield and P uptake by treatment of biological organic fertilizers, chemicals and conservation methods in andisol. This research was conducted in March-December 2017 in Pandansari Village, Paguyangan, Brebes and Soil Science Laboratory, Faculty of Agriculture, Jenderal Soedirman University, Purwokerto. The experimental design used was factorial Randomized Group Design (RAK) with three factors. The first factor is organic fertilizer $(P)$ with 6 levels consisting of P1 (control), P2 (POH 20 tons / ha), P3 (POH 15 tons / ha), P4 (POH 10 tons / ha), P5 (POH 5 tons / ha) and P6 (POH 2.5 tons / ha). The second factor is chemical fertilizer $(K)$ with 4 levels, namely K1 (control), K2 (recommended dosage and $200 \mathrm{~kg}$ of lime), K3 (1/2 recommended dose and $200 \mathrm{~kg}$ of lime) and K4 (1/4 recommended dose and $200 \mathrm{~kg}$ chalk). The third factor is the slope with 3 levels, which consists of L1 (control), L2 (10\% sloping contour parallel beds) and L3 (contour parallel beds). The variables observed were plant height, leaf number, potato yield, $\mathrm{H} 2 \mathrm{O} \mathrm{pH}$, and P. uptake. The results showed that biological and chemical organic fertilizers with soil conservation methods influenced the yield of potatoes in andisol and there was a correlation between potato yields and P uptake.
\end{abstract}

Keywords: P uptake, potato yield and andisol

\section{PENDAHULUAN}

Kentang merupakan salah satu komoditas sayuran yang memiliki nilai ekonomis tinggi. Berdasarkan data Dinas Pertanian dan Perkebunan Provinsi Jawa
Tengah (2017), produksi kentang Jawa Tengah pada tahun 2016 adalah sebanyak 2.729.758 kuintal. Produksi tersebut mengalami penurunan dari tahun sebelumnya. Kentang banyak 
dibudidayakan di tanah andisol. Salah satu tanah yang banyak digunakan untuk tanaman hortikultura adalah tanah yang berasal dari bahan induk abu volkan gunung api, yaitu Andisol.

Andisol merupakan jenis tanah yang berasal dari pelapukan material volkanik seperti abu volkan, sehingga menghasilkan mineral yang tidak berstruktur (non kristalin). Mineral ini mempunyai kapasitas yang tinggi dalam menahan unsur hara dan air, sehingga tanah ini sangat produktif dan subur. Andisol umumnya dijumpai pada dataran tinggi dengan kemiringan lereng yang relatif tinggi. Permasalahan yang muncul pada tanah ini adalah tingginya laju erosi, sehingga produktivitas tanah akan cepat menurun. Permasalahan lain yang sering ditemukan pada tanah Andisol adalah ketersediaan $\mathrm{P}$ yang rendah karena sebagian besar $\mathrm{P}$ dijerap oleh mineral alofan, oksida hidrat $\mathrm{Fe}$ dan $\mathrm{Al}$, serta kompleks Al-humus (Minardi dkk., 2011). Salah upaya untuk mengatasi hal tersebut adalah dengan menggunakan aplikasi pupuk organik hayati yang mengandung bakteri pelarut fosfat dan pupuk kimia yang mengandung P. Penelitian ini bertujuan untuk mengetahui pengaruh pupuk organik hayati dan kimia dengan metode konservasi tanah terhadap serapan P dan hasil kentang di andisol dan mengetahui hubungan hasil kentang dan serapan $\mathrm{P}$ dengan perlakuan pupuk organik hayati dan kimia dengan metode konservasi di andisol.

\section{METODE}

Penelitian tentang aplikasi pupuk organik hayati dan kimia dengan metode konservasi dilakukan di Desa Pandansari, Kecamatan Paguyangan, Kabupaten Brebes dengan ketinggian antara 1200 dan 2050 mdpl dan Laboratorium Ilmu Tanah Fakultas Pertanian, Universitas Jenderal Soedirman Purwokerto. Penelitian dilaksanakan pada bulan Maret sampai bulan Desember 2017.

Rancangan percobaan yang digunakan adalah RAK faktorial dengan tiga faktor. Faktor pertama yaitu pupuk organik $(\mathrm{P})$ dengan 6 taraf terdiri dari P1 (kontrol), P2 (POH 20 ton/ha), P3 (POH 15 ton/ha), P4 (POH 10 ton/ha), P5 (POH 5 ton/ha) dan P6 (POH 2,5 ton/ha). Faktor kedua yaitu pupuk kimia (K) dengan 4 taraf yang terdiri dari K1 (sesuai petani/kontrol), K2 (dosis anjuran yakni urea $300 \mathrm{~kg} / \mathrm{ha}$, SP$36500 \mathrm{~kg} / \mathrm{ha}, 300 \mathrm{~kg} \mathrm{KCl}$ dan $200 \mathrm{~kg}$ kapur), K3 (1/2 dosis anjuran dan $200 \mathrm{~kg}$ kapur) dan K4 (1/4 dosis anjuran dan 200kg kapur). Faktor ketiga yaitu lereng dengan 3 taraf yang terdiri dari L1 (bedengan sesuai petani/kontrol), L2 (bedengan sejajar kontur miring 10\%) dan L3 (bedengan sejajar kontur). Ketiga faktor tersebut dikombinasi sehingga terdapat 72 perlakuan yang diulang sebanyak 3 kali dan 3 kontrol sehingga sampel percobaan berjumlah 216 . 
Variabel yang diamati yaitu tinggi tanaman, jumlah daun, hasil kentang, $\mathrm{pH}$ $\mathrm{H}_{2} \mathrm{O}$, dan serapan $\mathrm{P}$.

Bahan yang digunakan dalam penelitian ini adalah pupuk organik hayati (POH) andisol, pupuk kimia (ZA, Phonska, Urea, SP-36, KCl, dan kapur dolomit), Bio P 60, Bio T 10, bibit kentang klon Granola, $\mathrm{KH}_{2} \mathrm{PO}_{4}, \mathrm{H}_{2} \mathrm{SO}_{4}, \mathrm{H}_{2} \mathrm{O}_{2}$, asam askorbat.

\section{HASIL DAN PEMBAHASAN}

\section{A. Pengaruh Pupuk Organik Hayati, Pupuk Kimia dan Metode Konservasi Tanah terhadap Pertumbuhan Kentang}

1. Tinggi tanaman

Penggunaan pupuk organik hayati berpengaruh terhadap tinggi tanaman, dengan hasil tertinggi yaitu P2 $(59,51 \mathrm{~cm})$ pada takaran 20 ton/ha (Tabel 1). Hal ini sesuai dengan pendapat Riyani (2013) bahwa pemberian pupuk kotoran ayam menyediakan unsur hara yang lebih baik. Meningkatnya tinggi tanaman pada perlakuan yang diberi pupuk kotoran ayam dipengaruhi oleh unsur $\mathrm{N}$ dan $\mathrm{P}$ yang terkandung di dalam pupuk kotoran ayam.
Kombinasi penggunaan pupuk kimia dan kelerengan (metode konservasi) terhadap tinggi tanaman dapat dilihat pada Tabel 2. Kombinasi tertinggi pada perlakuan L1K2 yaitu kombinasi L kontrol + Dosis anjuran (Urea 300 kg/ha, SP-36 500 kg/ha, 300 kg $\mathrm{KCl})$ dan $200 \mathrm{~kg}$ kapur. Hal ini terjadi karena semakin banyak unsur hara yang diberikan ke tanah akan semakin meningkatkan tinggi tanaman.

Menurut Lakitan (2012) cukupnya kebutuhan hara tanaman akan meningkatkan pertumbuhan tanaman dan sebaliknya, jika kebutuhan hara tanaman kurang mengakibatkan pertumbuhan tanaman terhambat. Pemupukan pada lahan yang mudah erosi kurang efisien dilakukan karena banyak unsur hara dan fraksi tanah halus yang terbawa erosi sehingga ketersediaan hara bagi tanaman sedikit. Interaksi ketiga perlakuan berpengaruh terhadap tinggi tanaman. Namun pada pengamatan tidak menunjukkan hasil yang terlalu berbeda pada setiap kombinasi perlakuan. Hal ini diduga karena dosis pupuk dan pengaruh erosi.

Tabel 1. Pengaruh pupuk organik hayati / $\mathrm{POH}(\mathrm{P})$ terhadap tinggi tanaman

\begin{tabular}{lc}
\multicolumn{1}{c}{ Dosis pupuk organik hayati } & Tinggi tanaman $(\mathrm{cm})$ \\
\hline P1 (Pupuk kandang kotoran ayam (20 ton/ha) & $58,69 \mathrm{a}$ \\
P2 (POH 20 ton/ha) & $59,51 \mathrm{a}$ \\
P3 (POH 15 ton/ha) & $56,62 \mathrm{a}$ \\
P4 (POH 10 ton/ha) & $58,28 \mathrm{a}$ \\
P5 (POH 5 ton/ha) & $59,16 \mathrm{a}$ \\
P6 (POH 2,5 ton/ha) & $50,73 \mathrm{~b}$ \\
\hline
\end{tabular}

Keterangan: Angka yang diikuti huruf berbeda pada kolom yang sama menunjukkan hasil yang berbeda nyata menurut DMRT pada taraf $5 \%$. 
Tabel 2. Pengaruh antara metode konservasi (L) dengan pupuk kimia (K) terhadap tinggi tanaman

\begin{tabular}{llll}
\hline \multicolumn{1}{c}{ Perlakuan } & & Tinggi Tanaman (cm) \\
\cline { 1 - 2 } Metode konservasi (L) & Pupuk kimia (K) & \\
\hline L1 (bedengan searah lereng) & K1 (sesuai petani) & & $57,61 \mathrm{a}-\mathrm{d}$ \\
& K2 (dosis anjuran) & & $63,17 \mathrm{a}$ \\
& K3 (1/2 dosis anjuran) & & $61,33 \mathrm{abc}$ \\
& K4 (1/4 dosis anjuran) & $56,78 \mathrm{a}-\mathrm{d}$ \\
\hline L2 (sejajar kontur miring 10\%) & K1 (sesuai petani) & & $57,18 \mathrm{a}-\mathrm{d}$ \\
& K2 (dosis anjuran) & & $53,27 \mathrm{~cd}$ \\
& K3 (1/2 dosis anjuran) & $62,05 \mathrm{ab}$ \\
& K4 (1/4 dosis anjuran) & $52,90 \mathrm{~d}$ \\
\hline L3 (sejajar kontur) & K1 (sesuai petani) & & $62,39 \mathrm{ab}$ \\
& K2 (dosis anjuran) & & $54,28 \mathrm{bcd}$ \\
& K3 (1/2 dosis anjuran) & $52,28 \mathrm{~d}$ \\
& K4 (1/4 dosis anjuran) & $52,44 \mathrm{~d}$
\end{tabular}

Keterangan: Angka yang diikuti huruf berbeda pada kolom yang sama menunjukkan hasil yang berbeda nyata menurut DMRT pada taraf $5 \%$.

Tabel 3. Pengaruh antara pupuk organik hayati $(\mathrm{POH} / \mathrm{P})$ dengan pupuk kimia $(\mathrm{K})$ terhadap jumlah daun

\begin{tabular}{|c|c|c|}
\hline \multicolumn{2}{|c|}{ Perlakuan } & \multirow[t]{2}{*}{ Jumlah daun } \\
\hline Pupuk Organik Hayati $(\mathrm{POH})(\mathrm{P})$ & Pupuk kimia (K) & \\
\hline \multirow{4}{*}{$\begin{array}{l}\text { P1 (Pupuk kandang kotoran ayam } \\
\text { (20 ton/ha)) }\end{array}$} & K1 (sesuai petani) & $307,22 \mathrm{abc}$ \\
\hline & K2 (dosis anjuran) & $331,67 \mathrm{abc}$ \\
\hline & K3 (1/2 dosis anjuran) & $359,89 \mathrm{a}$ \\
\hline & K4 (1/4 dosis anjuran) & $364,00 \mathrm{a}$ \\
\hline \multirow[t]{4}{*}{ P2 (POH (20 ton/ha)) } & K1 (sesuai petani) & $289,11 \mathrm{abc}$ \\
\hline & K2 (dosis anjuran) & $352,00 \mathrm{ab}$ \\
\hline & K3 (1/2 dosis anjuran) & $331,00 \mathrm{abc}$ \\
\hline & K4 (1/4 dosis anjuran) & $297,78 \mathrm{abc}$ \\
\hline \multirow[t]{4}{*}{ P3 (POH (15 ton/ha)) } & K1 (sesuai petani) & $309,56 \mathrm{abc}$ \\
\hline & K2 (dosis anjuran) & $258,00 \mathrm{bc}$ \\
\hline & K3 (1/2 dosis anjuran) & $370,44 \mathrm{a}$ \\
\hline & K4 (1/4 dosis anjuran) & $288,44 \mathrm{abc}$ \\
\hline \multirow[t]{4}{*}{ P4 (POH (10 ton/ha)) } & K1 (sesuai petani) & $375,78 \mathrm{a}$ \\
\hline & K2 (dosis anjuran) & $294,00 \mathrm{abc}$ \\
\hline & K3 (1/2 dosis anjuran) & 263,89 bc \\
\hline & K4 (1/4 dosis anjuran) & $342,33 \mathrm{abc}$ \\
\hline \multirow[t]{4}{*}{$\mathrm{P} 5$ (POH (5 ton/ha)) } & K1 (sesuai petani) & $284,78 \mathrm{abc}$ \\
\hline & K2 (dosis anjuran) & $304,22 \mathrm{abc}$ \\
\hline & K3 (1/2 dosis anjuran) & $381,22 \mathrm{a}$ \\
\hline & K4 (1/4 dosis anjuran) & $350,11 \mathrm{ab}$ \\
\hline \multirow[t]{4}{*}{ P6 (POH $(2,5$ ton/ha)) } & K1 (sesuai petani) & $327,78 \mathrm{abc}$ \\
\hline & K2 (dosis anjuran) & $323,33 \mathrm{abc}$ \\
\hline & K3 (1/2 dosis anjuran) & $291,44 \mathrm{abc}$ \\
\hline & K4 (1/4 dosis anjuran) & $245,56 \mathrm{c}$ \\
\hline
\end{tabular}

Keterangan: Angka yang diikuti huruf berbeda pada kolom yang samamenunjukkan hasil yang berbeda nyata menurut DMRT pada taraf 5\%. 
2. Jumlah daun

Tabel 3 menunjukkan kombinasi penggunaan pupuk organik hayati $(\mathrm{P})$ dan pupuk kimia $(\mathrm{K})$ berpengaruh terhadap jumlah daun, dengan hasil tertinggi diperoleh dari kombinasi P5K3 yaitu perlakuan Pupuk Organik Hayati sebanyak 5 ton/ha $+1 / 2$ dosis anjuran (Urea $150 \mathrm{~kg} / \mathrm{ha}$, SP-36 $250 \mathrm{~kg} / \mathrm{ha}, 150 \mathrm{~kg} \mathrm{KCl}$ ) dan $200 \mathrm{~kg}$ kapur. Hal ini berarti kombinasi pemupukan organik dan kimia berpengaruh positif terhadap pertumbuhan dan hasil tanaman kentang.

Menurut Rizqiani dkk. (2006), dengan pemberian pupuk organik, tanah sebagai media tumbuh tanaman dapat diperbaiki sifat fisik, biologi dan kimianya, sehingga penyerapan unsur hara oleh tanaman semakin meningkat dan dapat dimanfaatkan untuk pertumbuhannya dalam pembentukan daun. Pemberian pupuk kimia diduga meningkatkan unsur hara $\mathrm{N}$ yang berguna dalam pembentukan daun. Menurut Pramitasari dkk. (2016), unsur $\mathrm{N}$ bermanfaat untuk mempercepat pertumbuhan tinggi bagi tanaman, memperbanyak jumlah anakan, mempengaruhi jumlah, lebar dan panjang daun serta membuat menjadi besar, menambah kadar protein dan lemak bagi tanaman.

\section{B. Pengaruh Pupuk Organik Hayati dan Pupuk Kimia dengan Metode Konservasi Tanah terhadap Tanah dan Unsur Hara}

1. $\mathrm{pH} \mathrm{H}_{2} \mathrm{O}$ (pH Tanah)

Perlakuan L2 yakni dengan perlakuan metode konservasi sejajar kontur miring $10 \%$ menunjukkan hasil $\mathrm{pH}$ terbaik (Gambar 1). Hal ini diduga karena tanah mengalami erosi, sehingga $\mathrm{pH}$ pada berbagai lereng memiliki perbedaan. $\mathrm{pH}$ digunakan sebagai indikator kesuburan tanah. Halimas dkk. (2015) menyatakan hilangnya bahan organik lewat erosi tanah akan berakibat pada reaksi kimia tanah dan mempengaruhi kemasaman tanah. Hal inilah yang diduga menyebabkan tanah yang tidak menggunakan metode konservasi memilki pH yang lebih rendah.

Gambar 2 menunjukkan nilai $\mathrm{pH}$ paling tinggi didapat dengan perlakuan P5 yakni pemberian pupuk organik hayati 5 ton/Ha, namun jika dilihat tidak begitu berbeda dari perlakuan lainnya. Hal ini diduga karena pemberian perlakuan pemberian pupuk organik mampu meningkatkan pH. Nariratih dkk. (2013) menjelaskan pemberian bahan organik mampu meningkatkan nilai $\mathrm{pH}$ tanah, karena bahan organik memiliki kemampuan mengkhelat logam $\mathrm{Al}^{3+}$, sehingga tidak terjadi reaksi hidrolisis $\mathrm{Al}^{3+}$, dimana dari 


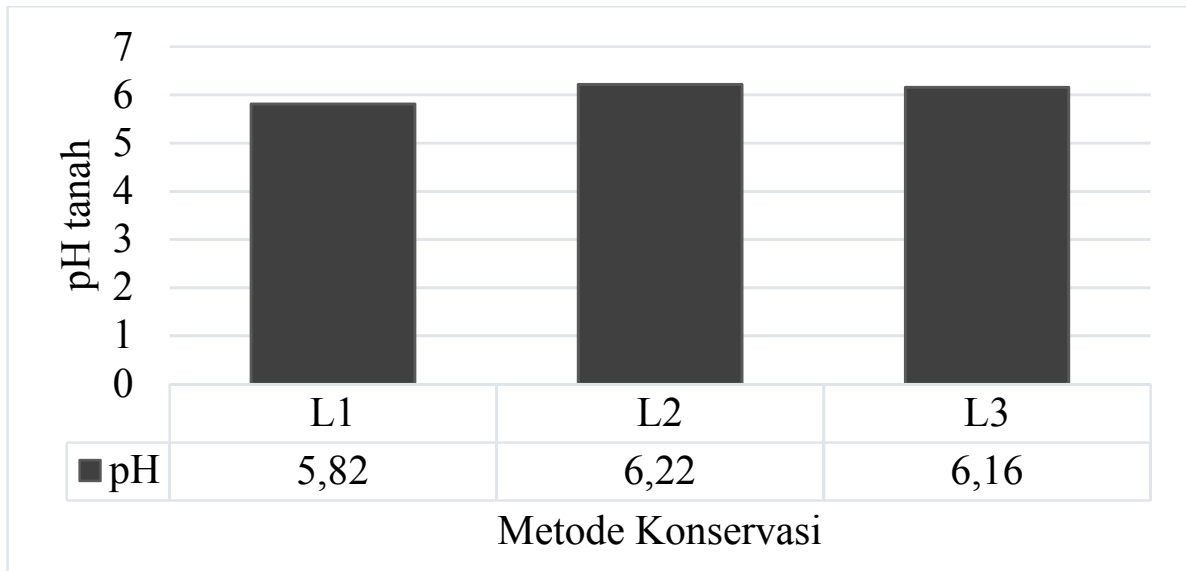

Gambar 1. pH tanah pada perlakuan metode konservasi.

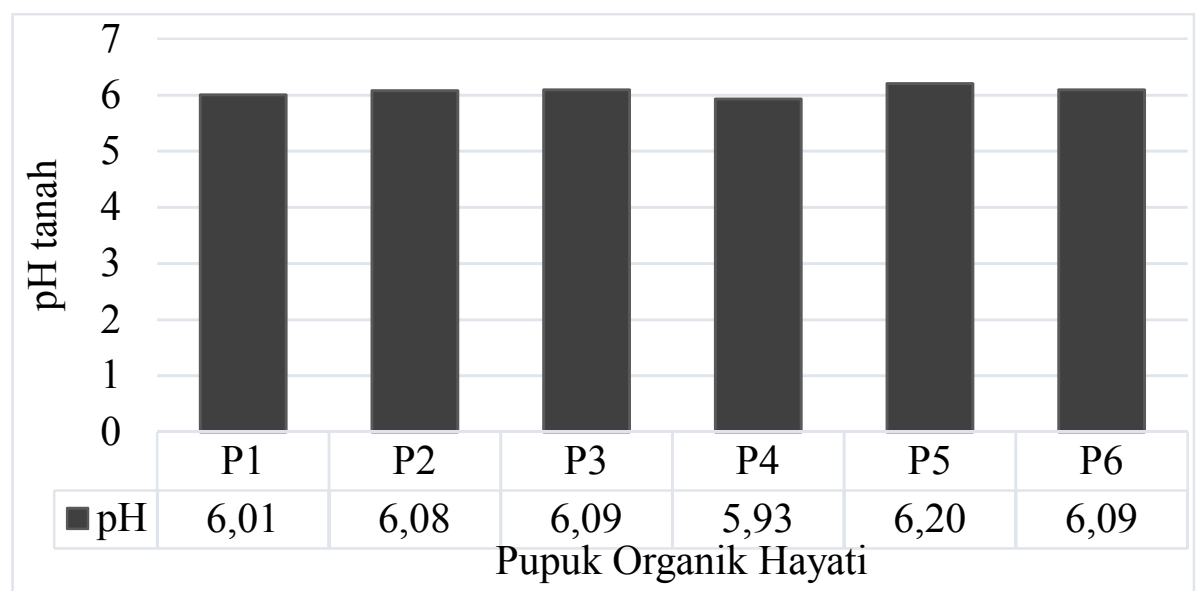

Gambar 2. pH tanah pada perlakuan pupuk organik hayati.

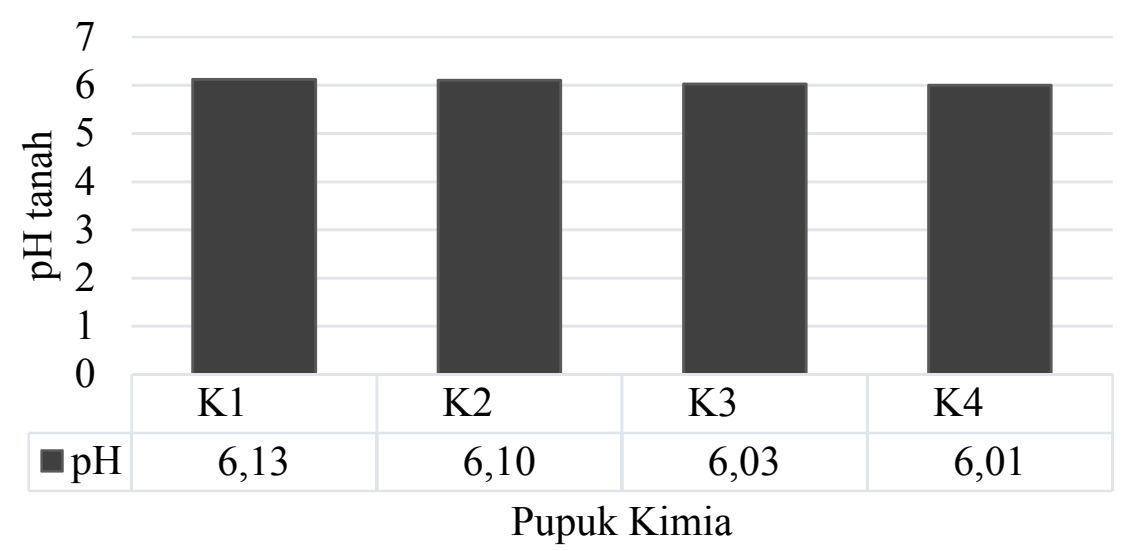

Gambar 3. $\mathrm{pH}$ tanah pada perlakuan pupuk kimia.

reaksi hidrolisis $\mathrm{Al}^{3+}$ dihasilkan 3 ion $\mathrm{H}^{+}$ yang dapat mengasamkan tanah bagi $\mathrm{pH}$ $\mathrm{H}_{2} \mathrm{O}$.

Gambar 3, pH tertinggi didapatkan dari penggunaan pupuk sesuai anjuran petani. Hal ini diduga bahwa urea yang memiliki kandungan $\mathrm{N}$ tinggi mampu menurunkan $\mathrm{pH}$ tanah. Firmansyah dan Sumarni (2013) mengemukakan bahwa pupuk yang mengandung nitrogen dalam bentuk amonia atau dalam bentuk lainnya dapat berubah menjadi nitrat yang berakibat 
pada penurunan $\mathrm{pH}$ tanah. Penambahan kapur pada perlakuan ternyata tidak begitu berpengaruh terhadap pH. Kamprath (1970) cit. Hasibuan (2008) menjelaskan untuk mendapatkan efisiensi pengapuran didaerah tropik basah dimana jumlah Al dd sangat tinggi ternyata pengapuran memang tidak perlu menambahkan $\mathrm{pH}$ diatas 6, tetapi cukup meniadakan atau menekan Al yang meracuni tanaman.

\section{Serapan $\mathbf{P}$}

Gambar 4 menunjukkan bahwa metode konservasi memberikan pengaruh bagi serapan $\mathrm{P}$. Nilai serapan $\mathrm{P}$ yang tertinggi ditunjukkan pada perlakuan L2 $(149,45)$ yakni perlakuan sejajar kontur miring 10\%. Hal ini diduga penggunaan metode konservasi berpotensi mencegah kehilangan unsur hara. Dariah dkk. (2014) menjelaskan bahwa dampak dari erosi selain menurunnya kualitas tanah, juga terangkutnya lapisan atas tanah yang subur. Unsur hara dan bahan organik baik yang terkandung dalam tanah maupun yang diaplikasikan dalam input usaha tani, tidak bisa dimanfaatkan secara optimal karena sebagian dari input hilang bersama erosi. Hal tersebut menunjukkan bahwa metode konservasi diperlukan agar unsur hara yang dibutuhkan tidak hilang bersamaan dengan erosi.

Perlakuan pemberian pupuk organik hayati juga memberikan pengaruh pada hasil serapan P seperti ditunjukkan pada Gambar
5. Perlakuan P5 $(172,37)$ atau pemberian pupuk organik hayati 10 ton/ha memberikan nilai serapan $\mathrm{P}$ tertinggi dibandingkan dengan yang lainnya. Pupuk organik hayati yang mengandung BPF meningkatkan kemampuan BPF dalam melarutkan $\mathrm{P}$, karena BPF menghasilkan asam organik, antara lain sitrat, malat dan asetat (David et al., 2009). P terlarut memudahkan tanaman dalam menyerap unsur $P$. Menurut Hermanto dkk. (2013), kenaikan pengambilan fosfor oleh tanaman berkaitan dengan peranan asam humat dalam meningkatkan efisiensi fosfor pada tanah karena proses pencegahan fiksasi $\mathrm{P}$ dalam tanah dan meningkatnya ketersediaan $\mathrm{P}$ bagi tanaman. Minardi dkk. (2011) menjelaskan bahwa pemberian pupuk organik mampu meningkatkan ketersediaan $\mathrm{P}$ dalam tanah sehingga memungkinkan penyerapan $\mathrm{P}$ yang tinggi oleh tanaman.

Pengaruh pemberian pupuk kimia terhadap serapan $\mathrm{P}$ dapat dilihat pada Gambar 6. Serapan $P$ paling tinggi didapatkan dari perlakuan K2 $(143,50)$ yakni pemberian pupuk sesuai dosis anjuran (Urea $300 \mathrm{~kg} / \mathrm{ha}+\mathrm{SP}-36500 \mathrm{~kg} / \mathrm{ha}+300 \mathrm{~kg} \mathrm{KCl}$ ) +200 kg kapur. Pemupukan kimia diduga dapat meningkatkan unsur hara dalam tanah. Menurut Firmansyah dan Sumarni (2013), penambahan unsur $\mathrm{N}$ dari pupuk kimia mampu meningkatkan efisiensi sistem perakaran dalam menyerap P. Pemberian pupuk SP-36 diduga memberikan hasil 


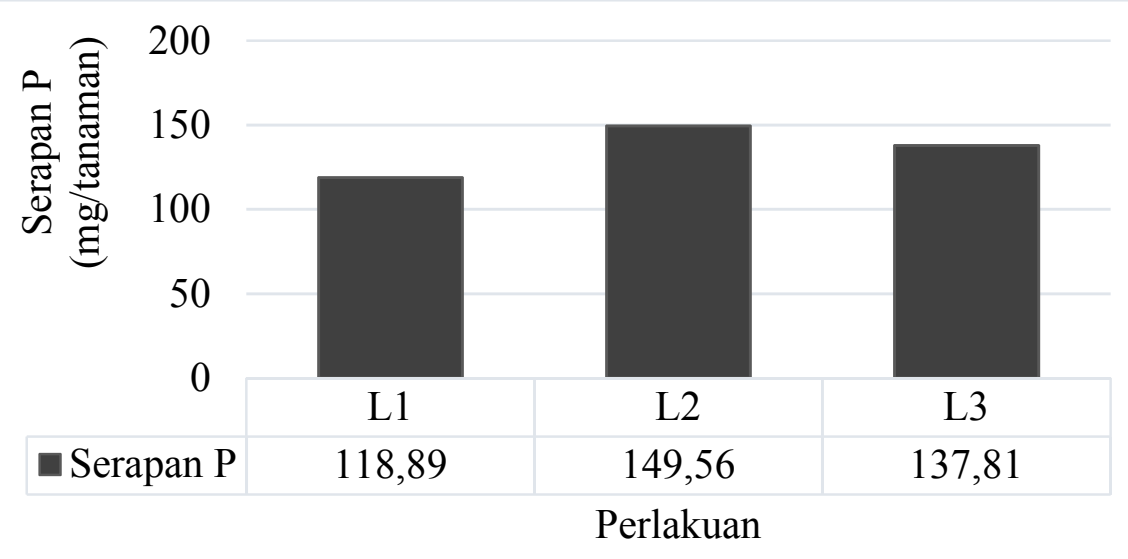

Gambar 4. Serapan P pada perlakuan metode konservasi.

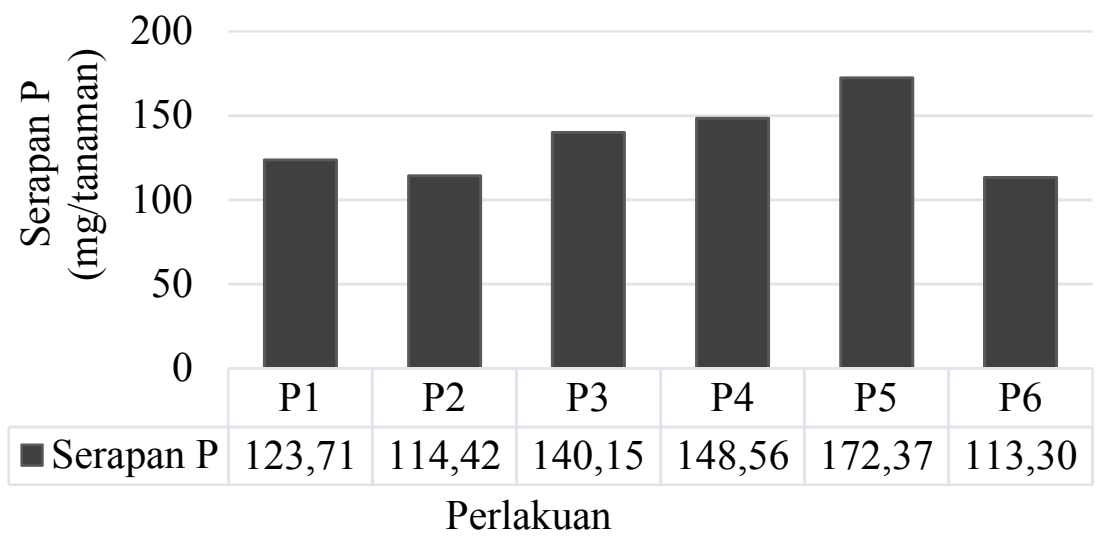

Gambar 5. Serapan P pada perlakuan perlakuan pupuk organik hayati.

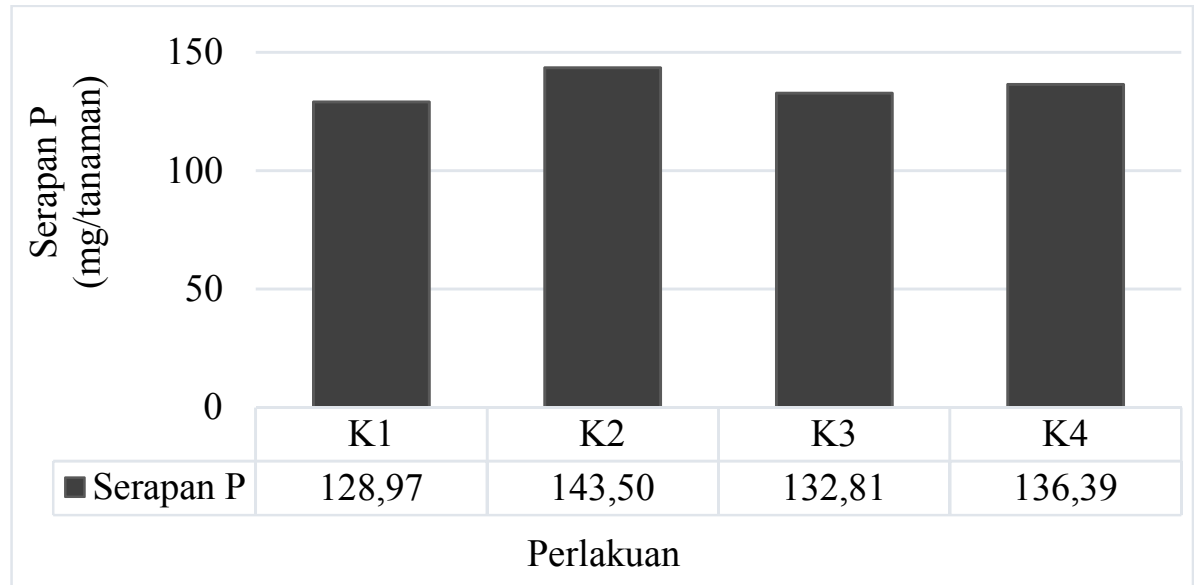

Gambar 6. Serapan P pada perlakuan pupuk kimia

terbaik karena dapat meningkatkan serapan

P. Hal ini sesuai dengan pendapat Pamuna (2013) bahwa SP-36 dapat meningkatkan serapan P tanaman.
C. Pengaruh Pupuk Organik Hayati dan Kimia dengan Metode Konservasi terhadap Hasil Kentang

Tabel 4 menunjukkan bahwa L2 (sejajar konturkemiringan 10\%) memberi 
Tabel 4. Pengaruh metode konservasi/kelerengan (L) terhadap hasil kentang per hektar

\begin{tabular}{lc}
\hline \multicolumn{1}{c}{ Metode konservasi } & Produksi per ha (ton) \\
\hline L1 (Sesuai dengan kemiringan lereng) & $22,79 \mathrm{~b}$ \\
L2 (Sejajar kontur kemiringan 10\%) & $32,09 \mathrm{a}$ \\
L3 (Sejajar kontur) & $31,47 \mathrm{a}$ \\
\hline
\end{tabular}

Keterangan: Angka yang diikuti huruf berbeda menunjukkan hasil yang berbeda nyata menurut DMRT pada taraf 5\%.

pengaruh pada variabel hasil kentang per hektar dengan nilai sebesar 32,09 ton/ha, akan tetapi tidak berbeda dengan L3 (sejajar kontur) yaitu sebesar 31,47ton/ha, sementara L1 berbeda dengan L2 dan L3 yaitu sebesar 22,79 ton/ha. Hal ini diduga karena tingkat erosi berpengaruh pada hasil kentang.

Nilai produki paling tinggi didapat dengan kombinasi perlakuan L2P3K2 yaitu sebesar 42,36 ton. L2P3K2 merupakan kombinasi perlakuan lereng sejajar kontur miring 10\% (L2), dan pemupukan pupuk organik hayati (P3) sebanyak 15 ton/ha dan pupuk kimia (K3) 1/2 dosis anjuran (Urea $150 \mathrm{~kg} / \mathrm{ha}$, SP-36 $250 \mathrm{~kg} / \mathrm{ha}, 150 \mathrm{~kg} \mathrm{KCl}$ ) dan $200 \mathrm{~kg}$ kapur. Hal ini berarti metode konservasi, pupuk organik hayati dan pupuk kimia memberikanpengaruh pada hasil kentang per hektar. Nilai hasil kentang paling tinggi didapat dengan perlakuan L2 akan tetapi tidak berbeda dengan L3. Hal ini diduga karena tingkat erosi berpengaruh pada hasil kentang. Erosi menyebabkan tanah kehilangan unsur hara yang terkandung di dalamnya. Salah satu cara mengurangi erosi adalah dengan metode konservasi. Menurut Burhannudin dkk.
(2015), kesuburan tanah menurun akibat terbawanya unsur hara bersama tanah yang tererosi.

Menurunnya kesuburan tanah akan berdampak pada menurunnya hasil tanaman. Perlakuan P3 juga memberikan nilai hasil kentang tertinggi yang berarti penggunaan pupuk organik hayati (P) memberi pengaruh pada hasil kentang per hektar. Hal ini sesuai dengan pendapat Rochmadhona (2017), berat buah akan semakin meningkat dikarenakan unsur hara yang dibutuhkan tanaman tercukupi dengan pemberian pupuk organik dan dosis yang tepat yang didalamnya. Lingga dan Marsono (2005) menyatakan bahwa kemampuan pupuk organik walaupun kuantitasnya sangat sedikit tetapi mampu memberikan pengaruh besar pada tanah yang bisa bermanfaat untuk meningkatkan produktivitas, mempercepat panen, merangsang pertumbuhan akar, batang, daun dan bunga. Perlakuan K3 menunjukkan hasil kentang paling besar. Perlakuan pemberian pupuk kimia dapat meningkatkan hasil maksimal. Hal ini diduga karena unsur hara yang dibutuhkan oleh tanaman yakni NPK dapat dipenuhi 
oleh tanaman sehingga pertumbuhan tanaman baik dan hasil meningkat. Menurut Pramitasari dkk. (2016), pemberian bahan organik dan pemberian pupuk anorganik dapat meningkatkan $\mathrm{pH}$ tanah, N-total, Ptersedia dan K-tersedia di dalam tanah, kadar dan serapan hara $\mathrm{N}, \mathrm{P}$, dan $\mathrm{K}$ tanaman, dan meningkatkan produksi tanaman.

\section{Hubungan Korelasi antara Serapan P dengan Hasil Kentang}

Berdasarkan hasil uji korelasi hasil kentang (metode konservasi) terhadap serapan $\mathrm{P}$ diperoleh koefisien korelasi sebesar 0,9458, hubungan yang terjadi tersebut berarti sangat kuat (Gambar 7, 8 dan 9). Besarnya hubungan antara hasil kentang (metode konservasi) dengan serapan $\mathrm{P}$ diduga karena adanya pengaruh erosi yang membawa unsur hara $\mathrm{P}$ sehingga tidak diserap oleh tanaman. Menurut Ferela (2008), hilangnya unsur-unsur hara termasuk unsur $\mathrm{P}$ karena erosi tanah menyebabkan tanah mencapai status kahat bagi tanaman kentang. Hal ini diduga menyebabkan hasil kentang pada lahan yang tidak dilakukan metode konservasi lebih rendah dibandingkan dengan lahan yang diberi perlakuan metode konservasi.

Hasil uji korelasi hasil kentang (pupuk organik hayati) terhadap serapan $\mathrm{P}$ diperoleh koefisien korelasi sebesar 0,7561, hubungan yang terjadi tersebut berarti kuat. Dari hasil tersebut didapatkan persamaan regresi $y=-15,727+0,5877 x-0,0019 x^{2}$ (Gambar 8). Perlakuan P5 memberikan hasil serapan dan hasil kentang tertinggi. Pemberian pupuk organik hayati yang memiliki kandungan pelarut fosfat didalamnya diduga dapat meningkatkan serapan $\mathrm{P}$ tanaman yang juga meningkatkan hasil kentang. Ritonga dkk. (2015) menjelaskan bakteripelarut fosfat dan bahan organik, masing-masing dapat menghasilkan asam organik yang mengkhelat logam dalam tanah sehingga fosfat menjadi tersedia bagi tanaman. Pemberian BPF dan bahan organik akan meningkatkan ketersediaan $\mathrm{P}$ di dalam tanah yang juga berpengaruh pada peningkatan produksi tanaman.

Dari hasil uji korelasi hasil kentang (pupuk kimia) terhadap serapan $\mathrm{P}$ diperoleh koefisien korelasi sebesar 0,4973, hubungan yang terjadi tersebut berarti tidak kuat. Dari hasil tersebut didapatkan persamaan regresi $y=866,4-12,415 x$ $0,0459 x^{2}$ (Gambar 9). Pemberian pupuk kimia yang mengandung $\mathrm{P}$ pada SP-36 dapat meningkatkan serapan P. Menurut Ferela (2008), fungsi P yaitu mendukung pertumbuhan generatif dalam meningkatkan berat umbi kentang. Perlakuan K2 yakni pupuk kimia sebanyak dosis yang dianjurkan yang berupa pupuk Urea $300 \mathrm{~kg} / \mathrm{ha}$, SP-36 $500 \mathrm{~kg} / \mathrm{ha}, 300 \mathrm{~kg}$ $\mathrm{KCl}$ dan $200 \mathrm{~kg}$ memberikan nilai serapan tertinggi juga hasil tanaman. 
p-ISSN: 1410-0029; e-ISSN2549-6786

Agrin Vol. 22, No. 2, Oktober 2018

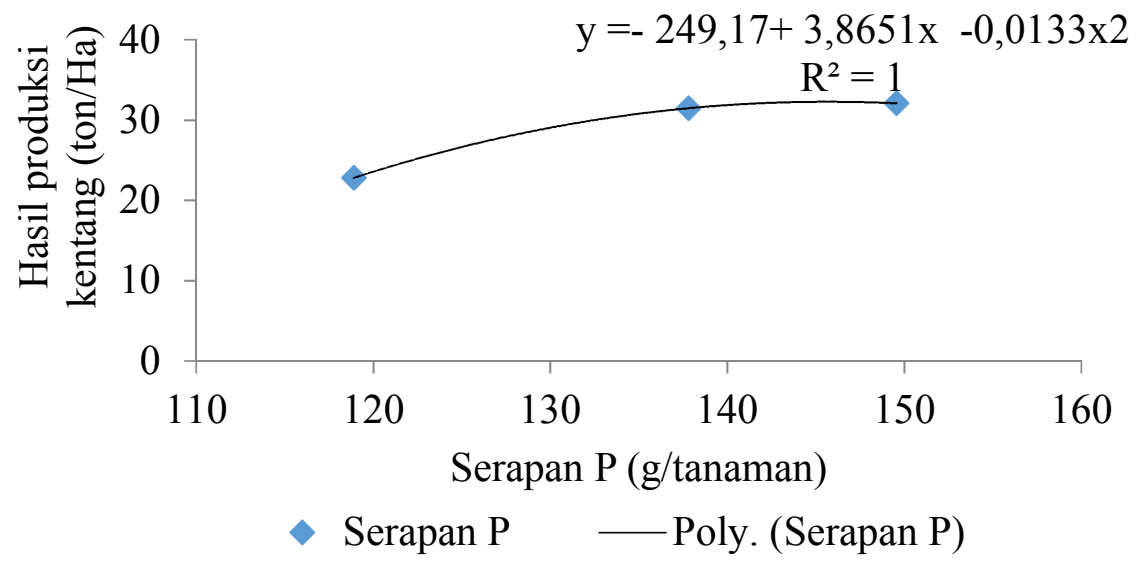

Gambar 7. Uji korelasi hasil produksi kentang dengan serapan P terhadap perlakuan metode konservasi.

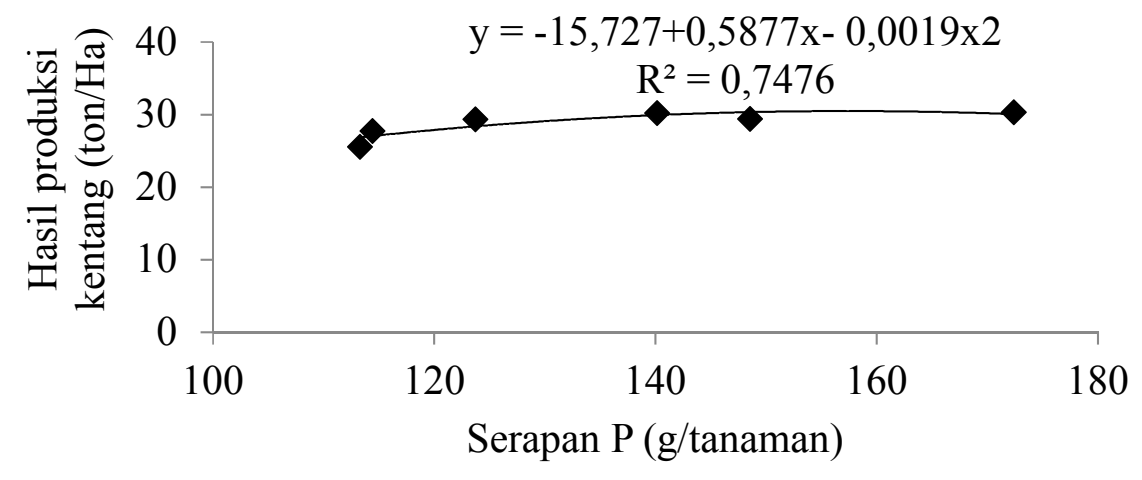

- Serapan P — Poly. (Serapan P)

Gambar 8. Uji korelasi hasil produksi kentang dengan serapan P terhadap perlakuan pupuk organik hayati.

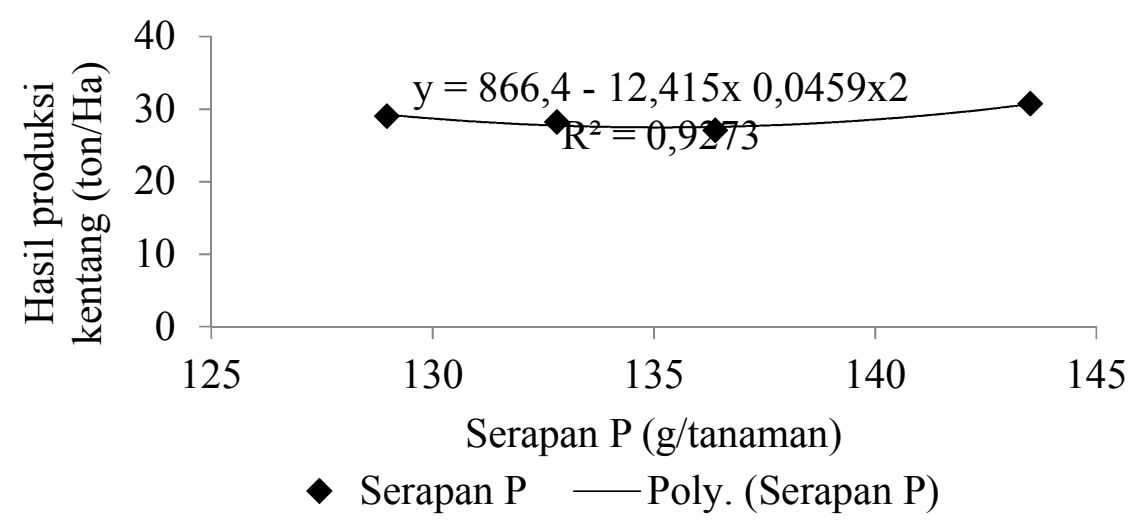

Gambar 3. Uji korelasi hasil produksi kentang dengan serapan P terhadap perlakuan metode perlakuan pupuk kimia.

\section{KESIMPULAN}

1. Aplikasi pupuk organik hayati, kimia dan metode konservasi memberikan pengaruh pada hasil kentang, ditunjukkan dengan hasil kentang tertinggi diperoleh dari perlakuan L2P3K3 (42,36 ton/ha) yakni perlakuan sejajar kontur dengan 
kemiringan $10 \%$ dengan pemberian pupuk organik hayati sebanyak 15 ton/ha dan pemberian pupuk kimia $1 / 2$ dosis yang dianjurkan meliputi Urea $150 \mathrm{~kg} / \mathrm{ha}, \mathrm{SP}-36250 \mathrm{~kg} / \mathrm{ha}, 150 \mathrm{~kg}$ $\mathrm{KCl}$ dan 200 kg kapur.

2. Terdapat hubungan antara serapan $\mathbf{P}$ dengan hasil kentang ditunjukkan oleh nilai korelasi yang ada yakni hubungan kuadratik.

\section{DAFTAR PUSTAKA}

Burhannudin, I. S. Banuwa, dan I. Zulkarnain. 2015. Pengaruh sistem olah tanah dan herbisida terhadap kehilangan unsur hara dan bahan organik akibat erosi di laboratorium lapangan terpadu Fakultas Pertanian, Universitas Lampung. Jurnal Teknik Pertanian Lampung, 3(3): 275 - 282.

Dariah, A., N. L. Nurida. dan Sutono. 2014. Aplikasi teknik konservasi untuk menekan kehilangan hara dan bahan organik pada lahan kering beriklim beriklim kering berbasis tanaman semusim. Prosiding Seminar Nasional Inovasi Pertanian Lahan Kering. Balai Besar Pengkajian dan Pengembangan Teknologi Pertanian. Badan Litbang Pertanian. Kementrian Pertanian. Bogor.

David, E. V., L.L. Reyes, dan A.D.L.C. Benitez. 2009. Use of 16S rRNA gene for characterization of phosphate solubilizing bacteria associated with corn. Revista Fitotecnia. Mexicana, 32(1): $31-37$.

Dinas Pertanian dan Perkebunan Provinsi Jawa Tengah. 2017. Statistika hortikultura provinsi jawa tengah. Dinas Pertanian dan Perkebunan Provinsi Jawa Tengah, Jawa Tengah.
Ferela, B. D., 2008. Efisiensi serapan P pada Andisols Tawangmangu dengan penambahan vermikompos dan kentang (Solanum tuberosum L.) sebagai Indikator. Skripsi. Fakultas Pertanian. Universitas Sebelas Maret, Surakarta.

Firmansyah, I. dan N. Sumarni. 2013. Pengaruh dosis pupuk $\mathrm{n}$ dan varietas terhadap $\mathrm{pH}$ tanah, N-Total tanah, serapan $\mathrm{N}$, dan hasil umbi bawang merah (Allium ascalonicum L.) pada tanah entisols-Brebes Jawa Tengah. Journal of Horticulture, 23(4): 358 364.

Halimas, A. W., A. Rauf dan Mukhlis. 2015. Kajian erosi kualitatif pada budidaya tanaman karet rakyat usia 15 tahun di Desa Lau Damak, Kecamatan Bahorok, Kabupaten Langkat. Jurnal Agroekoteknologi, 3(4): $1601-1607$.

Hasibuan. 2008. Pupuk dan pemupukan. USU Press, Medan.

Hermanto, D., N.K.T. Dharmayani, R. Kurnianingsih, dan S.R. Kamali. 2013. Pengaruh asam humat sebagai pelengkap pupuk terhadap ketersediaan dan pengambilan nutrien pada tanaman jagung di lahan kering Kec. Bayan-NTB. J. Ilmu Pertanian, 16(2): $28-41$.

Lakitan, B. 2012. Dasar-dasar fisiologi tumbuhan. Rajawali Press, Jakarta.

Lingga, P dan Marsono. 2005. Petunjuk penggunaan pupuk. Penebar Swadaya, Jakarta.

Minardi, S., J. Syamsiyah dan S. Sukoco. 2011. Pengaruh bahan organik dan pupuk fosfor terhadap ketersediaan dan serapan fosfor pada andisols dengan indikator tanaman jagung (Zea mays). Jurnal Ilmu Tanah dan Agroklimatologi, 8(1): 23 - 30.

Nariratih, I., M. M. B. Damanik dan G. Sitanggang. 2013. Ketersediaan nitrogen pada tiga jenis tanah akibat 
pemberian tiga bahan organik dan serapannya pada tanaman jagung. Jurnal Online Agroekoteknologi. 1(3): $479-488$.

Pamuna, K., S. Darman. dan Y.S. Pata'dungan. 2013. Pengaruh pupuk SP-36 dan fungsi Mikoriza arbuscula terhadap serapan fosfat tanaman jagung (Zea Mays L.) pada Oxic Distrudepts Lemban Tongoa. $J$. Agrotekbis., 1(1): 23 - 29.

Pramitasari, H. E., T. Wardiyati dan M. Nawawi. 2016. Pengaruh dosis pupuk nitrogen dan tingkat kepadatan tanaman terhadap pertumbuhan dan hasil tanaman kailan (Brassica oleraceae L.). Jurnal Produksi Tanaman, 4(1): 49-56.

Ritonga, M., Bintang, dan M. Sembiring, 2015. Perubahan bentuk $P$ oleh mikroba pelarut fosfat dan bahan organik terhadap P-tersedia dan produksi kentang (Solanum tuberosum L.) pada tanah Andisol terdampak erupsi Gunung Sinabung. Jurnal Agroekoteknologi, 4(1): 1641 -1650 .

Riyani, R. 2013. Pengaruh berbagai pupuk organik terhadap pertumbuhan dan hasil padi di lahan pasang surut. Skripsi. Fakultas Pertanian, Universitas Tanjungpura Pontianak.

Rizqiani, N. F., E. Ambarwati dan N.W. Yuwono. 2006. Pengaruh dosis dan frekuensi pemberian pupuk organik cair terhadap pertumbuhan dan hasil buncis (Phaseolus vulgaris L.) dataran rendah. Jurnal Ilmu Pertanian, 13(2): 163 - 178.

Rochmadhona, V. U. 2017. Pengaruh pupuk organik terhadap hasil panen dan daya simpan buah naga merah (Hylocereus polyrhizus) sebagai desain sumber belajar biologi SMA. Jurnal Lentera Pendidikan Pusat Penelitian, 2(1): 34 - 48. 